$$
\begin{aligned}
& \text { المعالجة الفيزيو كيمياوية لمياه فضلات مجمع المستشفيات بالموصل } \\
& \text { حل نبيل ايليا } \\
& \text { مدرس مساعد } \\
& \text { قسم الهنسية المدنية / كلية الثهنسة / جامعة الموصل } \\
& \text { الخلاصة الخدة }
\end{aligned}
$$

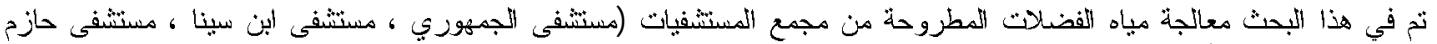

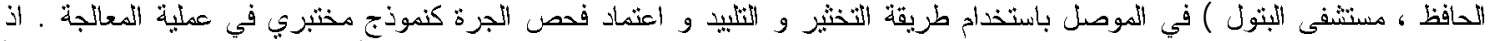

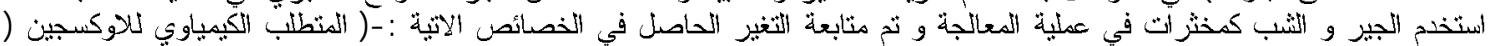

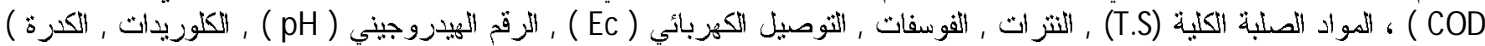

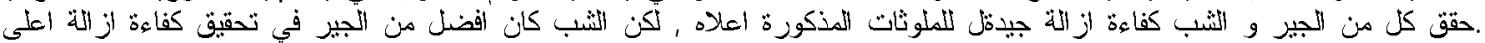

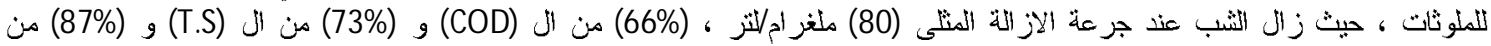

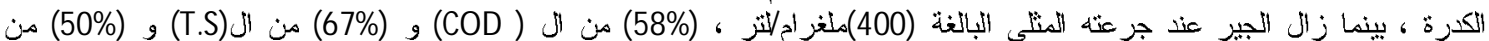

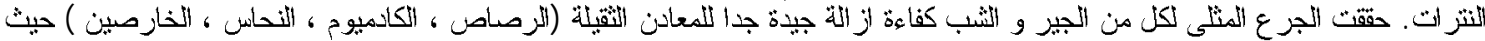

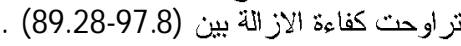

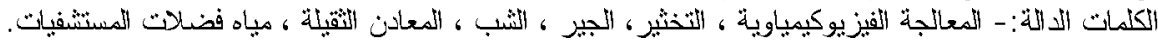

\title{
PHYSIOCHEMICAL TREATMENT OF SEVERAL HOSPITALS WASTEWATER IN MOSUL CITY HALLA NABEEL ELEA
}

\author{
DEPT OF CIVIL ENGINEERING/COLLEGE OF ENGINEERING/UNIVERCITY OF MOSUL
}

\begin{abstract}
This study aimed to treat the wastewater of several hospitals (Jamhory Hospital , Ibn-Sina Hospital , Batool Hospital , Hazem Al-Hafez Hospital) in Mosul city, by using the method of coagulation and flocculation and by using the Jar_Test as a laboratory scale. Alum and Lime were used as coagulants in wastewater treatment. The efficiency had been calculated by the following characteristics :- ( Chemical Oxygen Demand (COD), Total Solids Matter (T.S), Nitrate (NO3) , Phosphate (PO4) , (pH) , Electrical Conductivity (Ec) , Chloride , Turbidity ). At the optimum dose of alum (80) mg/l removal efficiencies were (66\%) for (COD), (73\%) for (T.S) and (87\%) for Turbidity . the Nitrate removal efficiency was (65\%) at the optimum dose $(60) \mathrm{mg} / \mathrm{l}$. The optimum dose of Lime was (400) mg/l for removal (COD) , (T.S) and Nitrate, the removal efficiency of (COD) was ( 58\%), (67\%) for (T.S) and (50\%) for Nitrate. The Alum was better than Lime in removal efficiencies of pollutants from hospitals wastewater. The heavy metals removal efficiency at the optimum doses were ranged from ( 89.2897.8)\% .

Key words:- Physiochemical Treatment, Hospitals Wastewater , Heavy M etals, Alum, Lime, Coagulation.
\end{abstract}




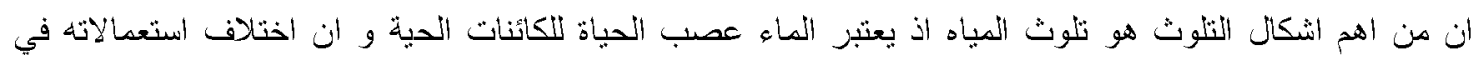

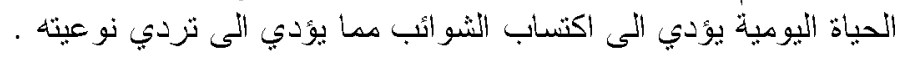

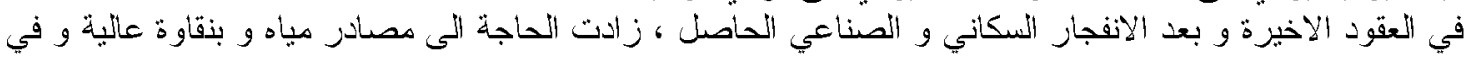

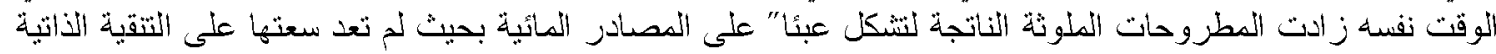

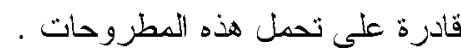

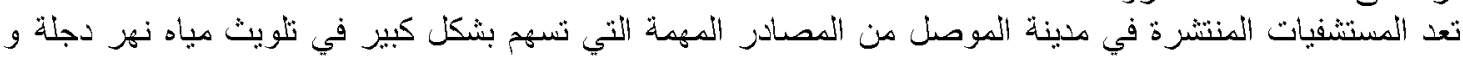

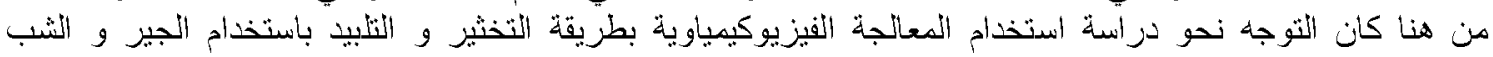

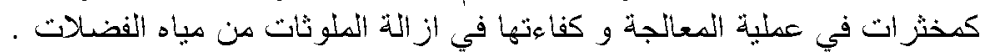

$$
\text { أهداف البحث: : - }
$$

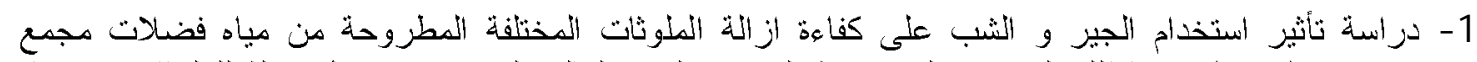

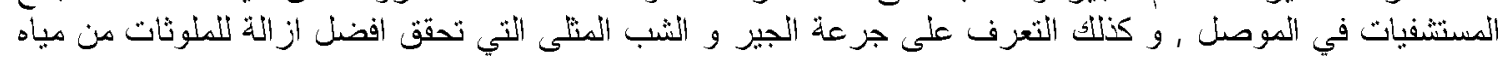
الفضلات.

2 - التعرف على فاعلية كل من الجير و الثب عن طريق هتابعة التغير في الخصائص الاتية: -

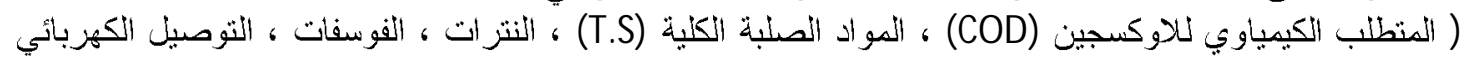

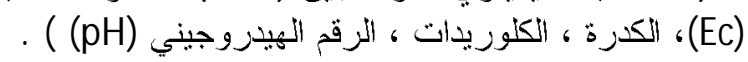

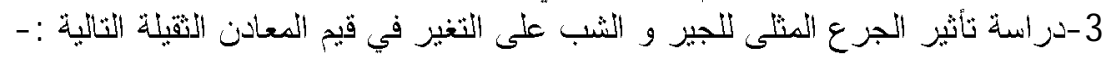

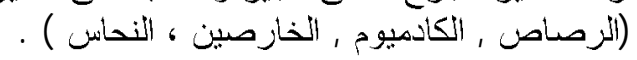

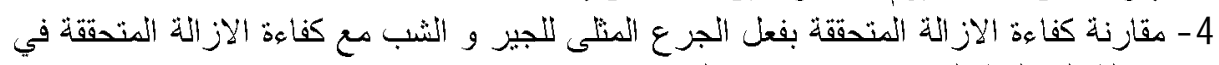

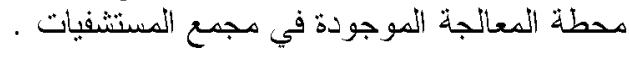

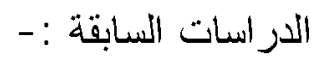

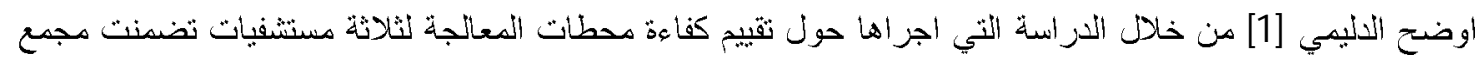

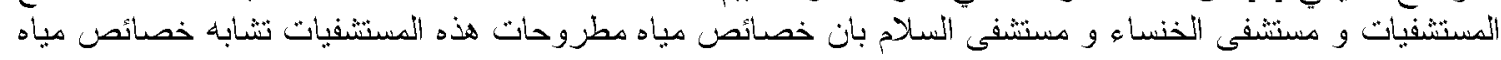

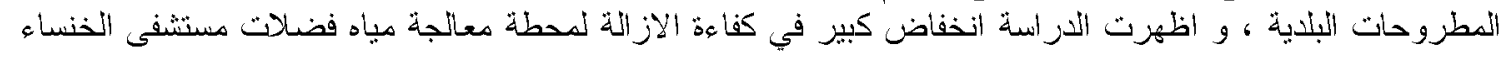

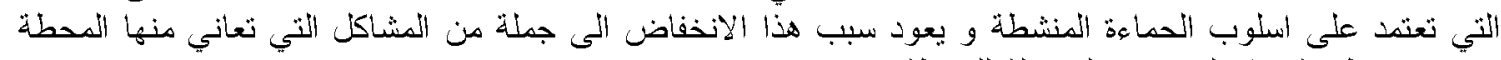

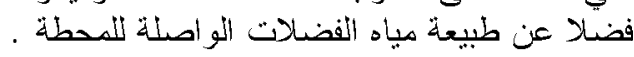

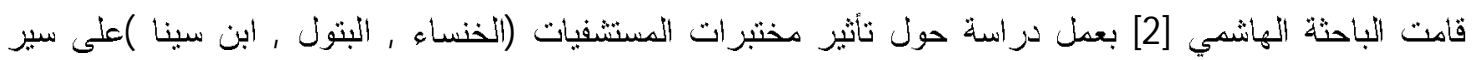

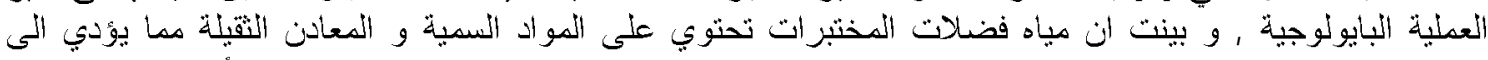

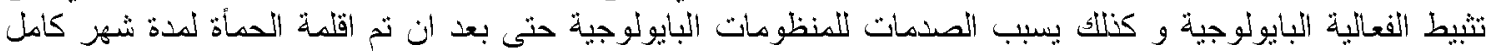

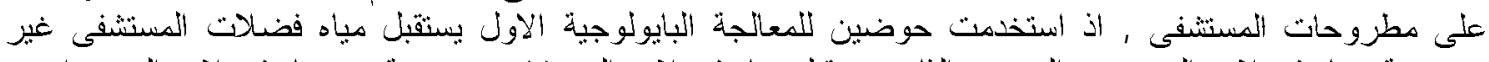

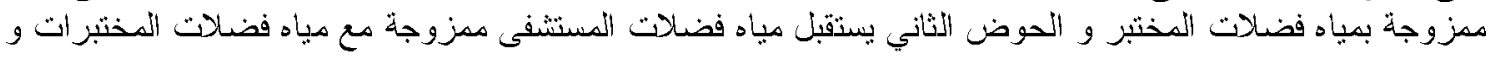

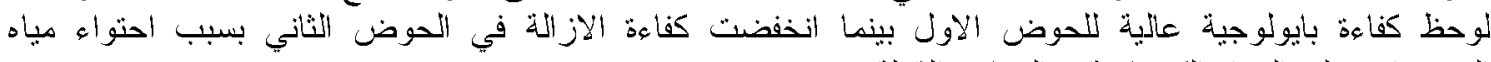

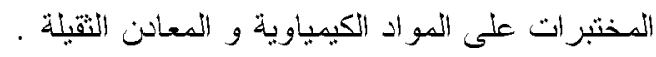

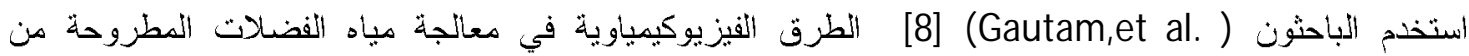

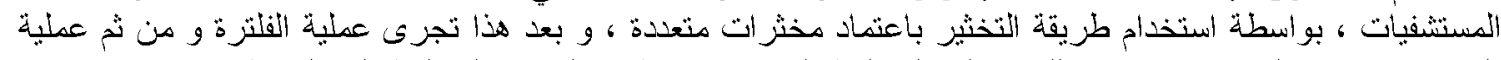

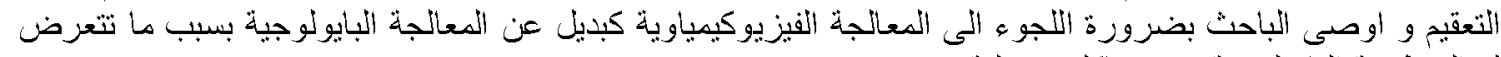

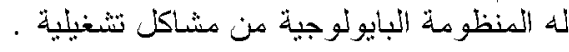

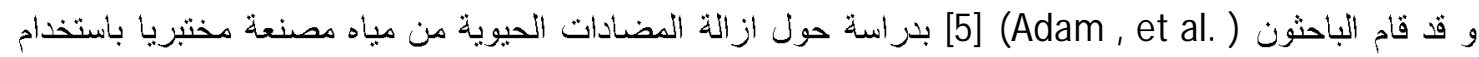

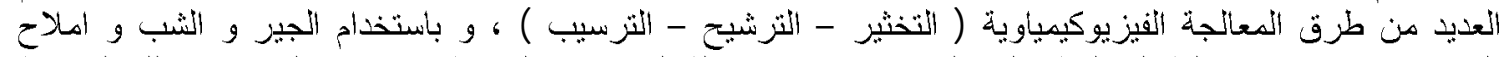

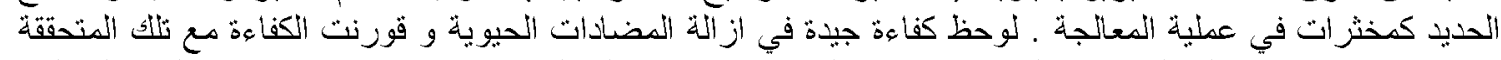

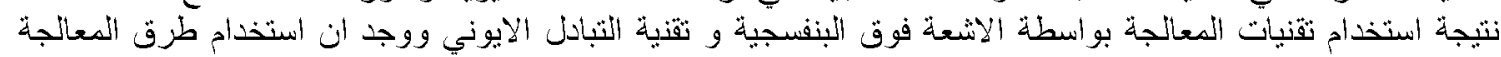

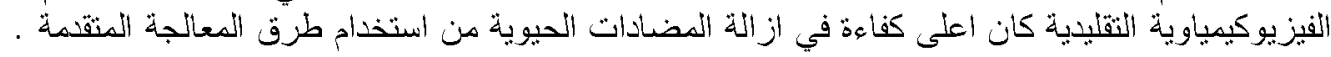

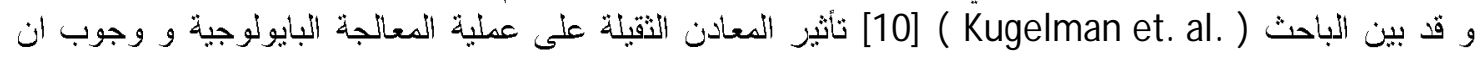

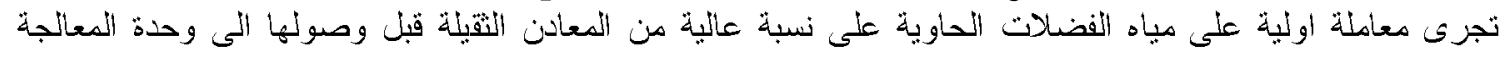

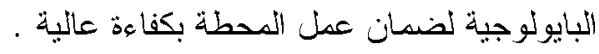




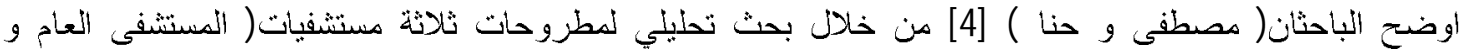

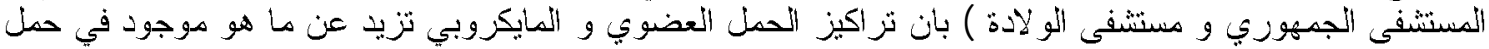

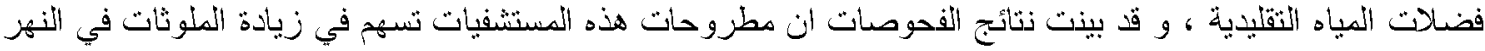

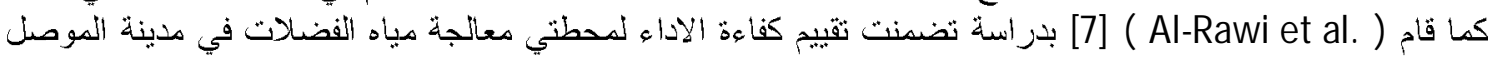

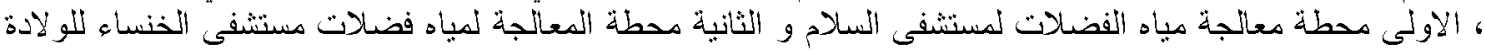

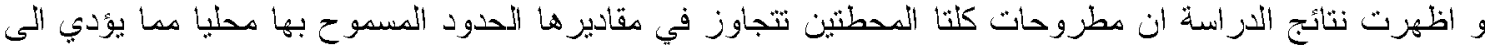

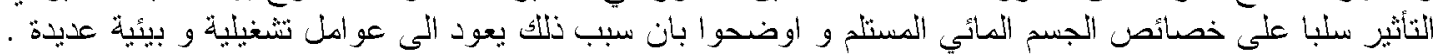

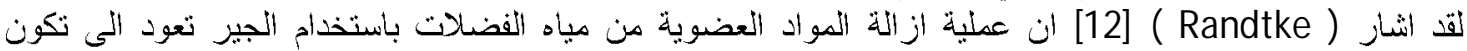

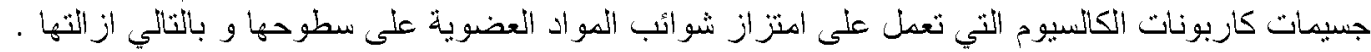

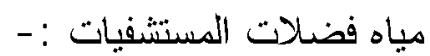

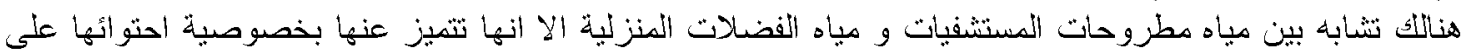

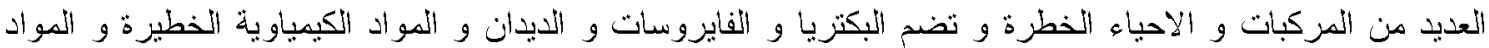

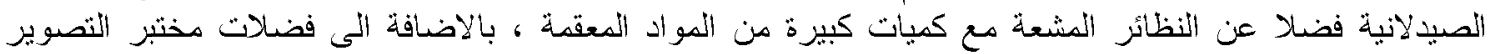

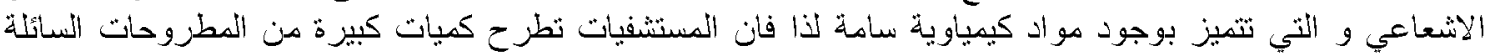

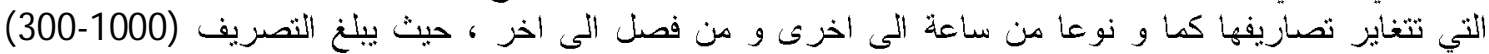

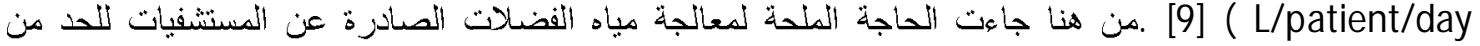

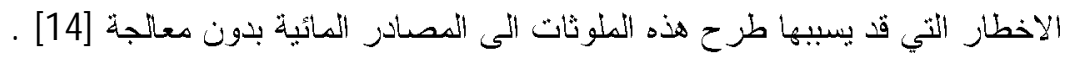

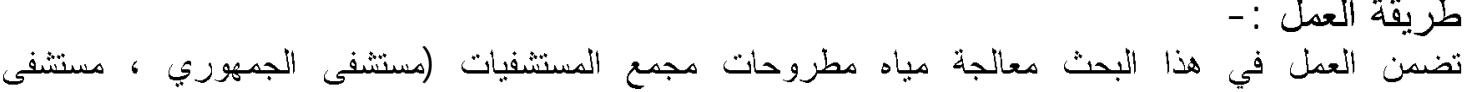

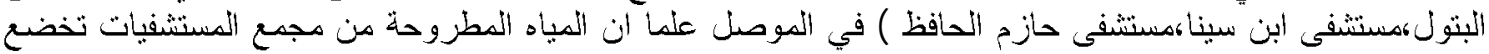

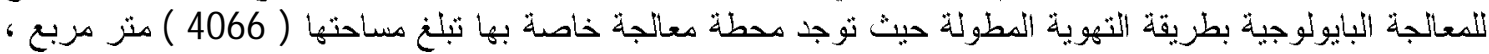

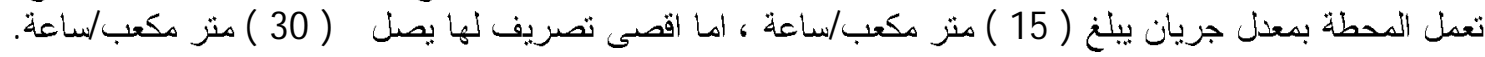

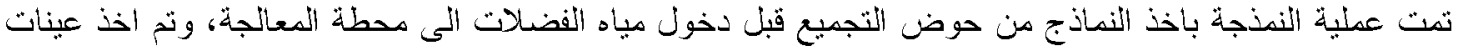

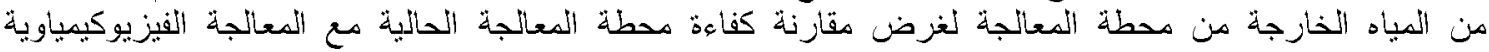

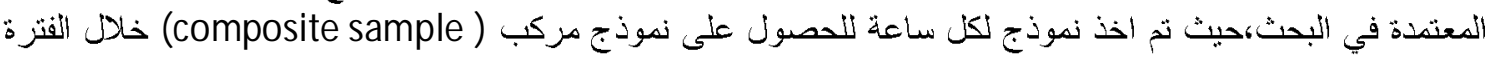

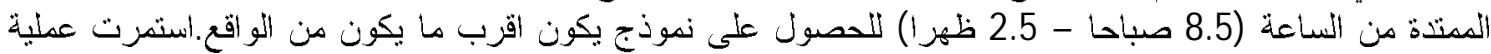
النذجة من شهر ( ايلول 2008 - كانون الاول

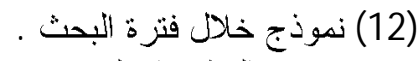

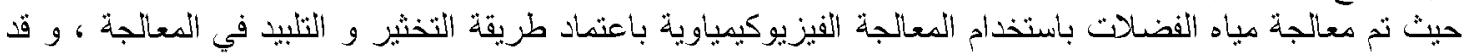

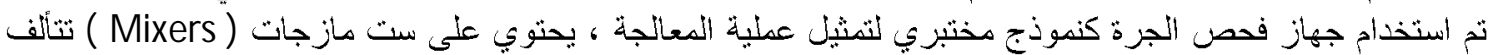
كل مازجة من اثثين من المجاذيف ( Paddles ) ، ذات شكل مربع ابعادها (2×2) سم ، و البيكرات التي استخمت

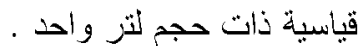

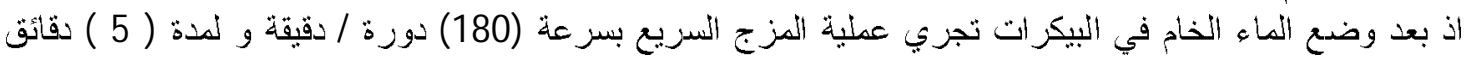

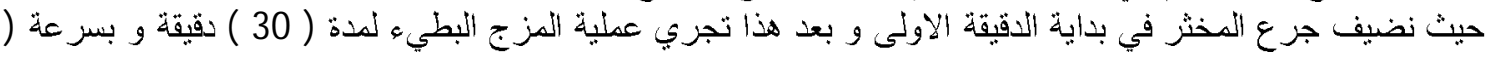

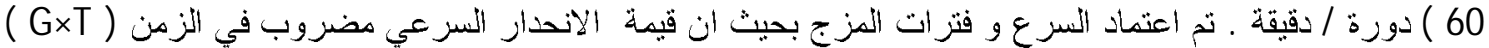

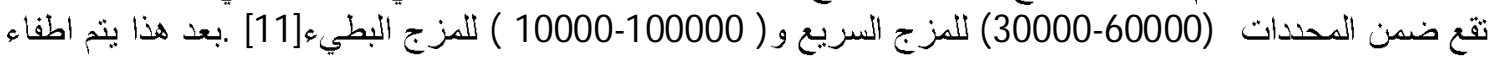

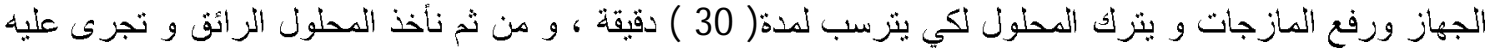

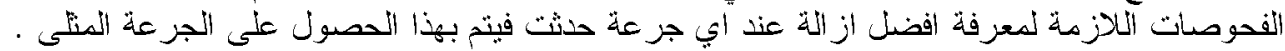

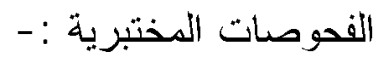

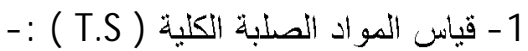

تم قيانس المو اد الصلبة الكلية باعتماد الطريقة الوزنية القباسية و باستخدام مبزان الكتروني

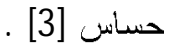

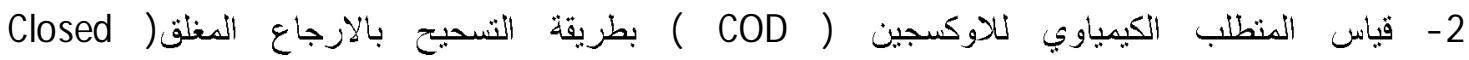


3 - قياس النترات بطريقة (13] (Ultraviolet Spectrophotometer Screening M ethod).

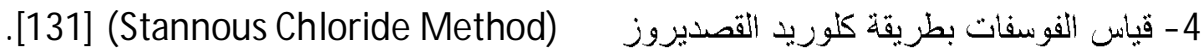

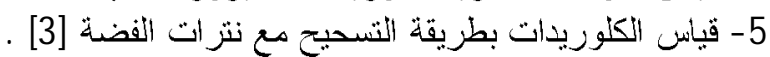

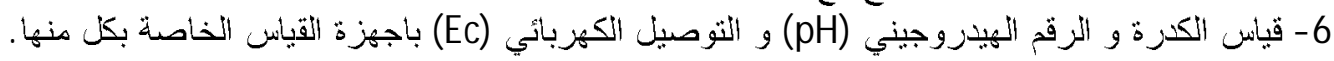

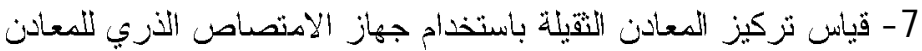

. (Atomic Absorption Spectrophotometer)

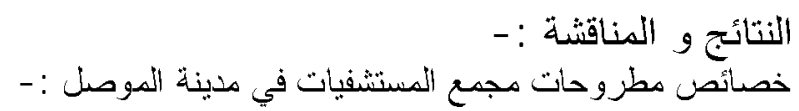

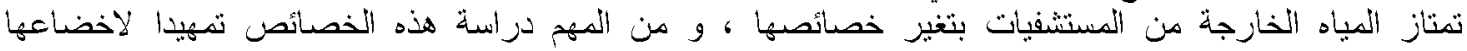

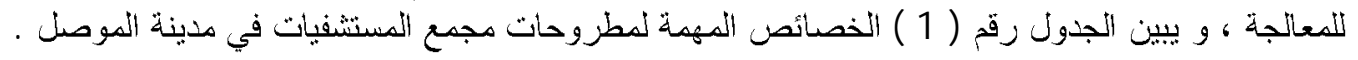

جدول رقم (1) يوضح الخصائص و مديات تراكيز ها للمطروحات الخام التي تم قيانسها خلال فنرة البحث لمطروحات

\begin{tabular}{|c|c|c|c|}
\hline 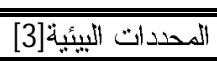 & (المد ज & الخاصية & ت \\
\hline--- & 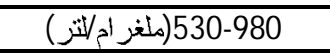 & الموايد الصلبة الكلية (T.S) & 1 \\
\hline 100 & 200-835(ملغزر إح/تزر) & الكنطلب الكيمياو ي للاوكسبين (COD) & 2 \\
\hline 3 & 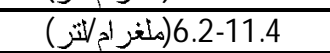 & (PO4) الفو سفات & 3 \\
\hline 50 & 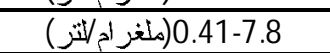 & النتزات ( N03 ) & 4 \\
\hline 200 & 38-53 (ملغر اج//iتزر) & الكلوريشات (Cl ) & 5 \\
\hline$-\cdots$ & 640-1200 (مايكروموز //م) & التوصيل الكهز بائى ( EC ) & 6 \\
\hline $9.5-6$ & $6.6-7.9$ & الرقق الهيدرو جيني ( pH ) & 7 \\
\hline$-\overline{-}$ & ( NTU ) 37-68 & الككرة: & 8 \\
\hline 0.1 & 0.1-0.33 (ملغر اج/لازر) & الزصاص (pb) & 9 \\
\hline 0.01 & 0.04-0.24 (ملغز إج/تنز) & الكادميور (cd) & 10 \\
\hline 2 & 1.2-4.5 (ملغر آ//لنز) & الخارصين (Zn) & 11 \\
\hline 0.2 & 0.36-1.87 (مغنغ اد/نتزر) & النحاس (Cu) & 12 \\
\hline
\end{tabular}

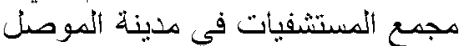

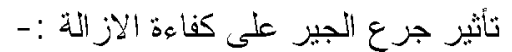

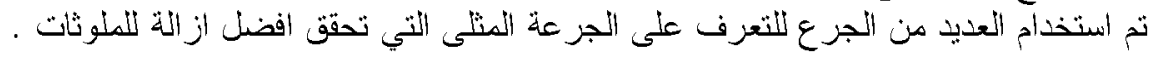

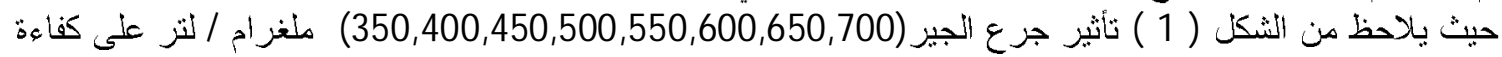

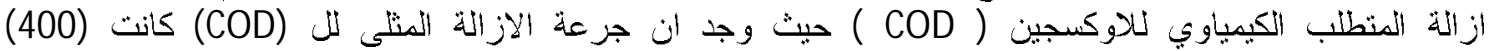

ملغر ام/لتز، الذ حقتت ازالة مقار ها (58\%) .

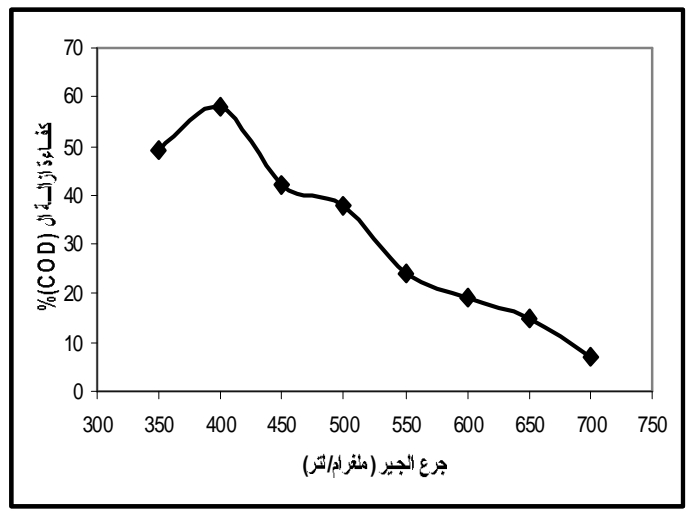

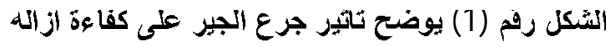

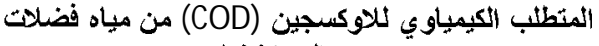
مجمع المسثنفيات

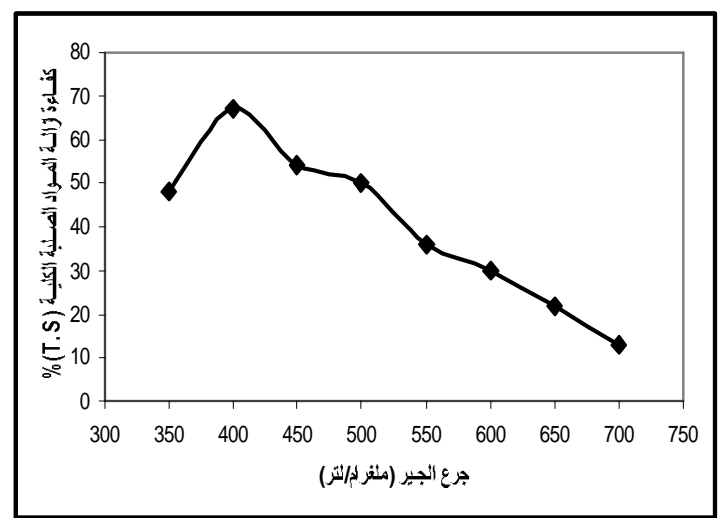

الثكل رقم (2) يوضح تأثبر جرع الجير عنى كفاعة از الثة

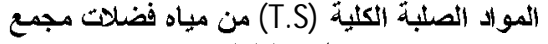
المستثفيات من مال 
وبالنسبة للمو اد الصلبة الكلية فقد بلغت كفاءة الاز انة (67\%) عند الجرعة المثلى البالغة (400) ملغز ام/لتز كما يلاحظ

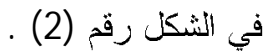

و قد زالت الجرعة المنلى لاز الة الفوسفات (85\%) و التي بلغ مقارها (600) ملغرام/لتز كما مبين في الشكل رقم

اما بالنسبة للنترات الموضحة في الشكل(4) فقد كانت اعلى كفاءة ازالة (50\%) عند الجرعة (400) ملغرام/التر .

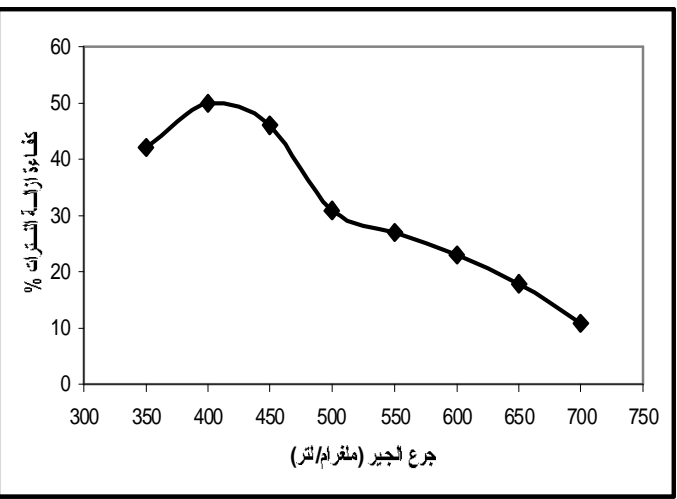

الثكل رتم (4) يوضح تأثير جرع الجيز على كفاءة ازائة

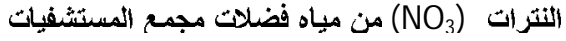

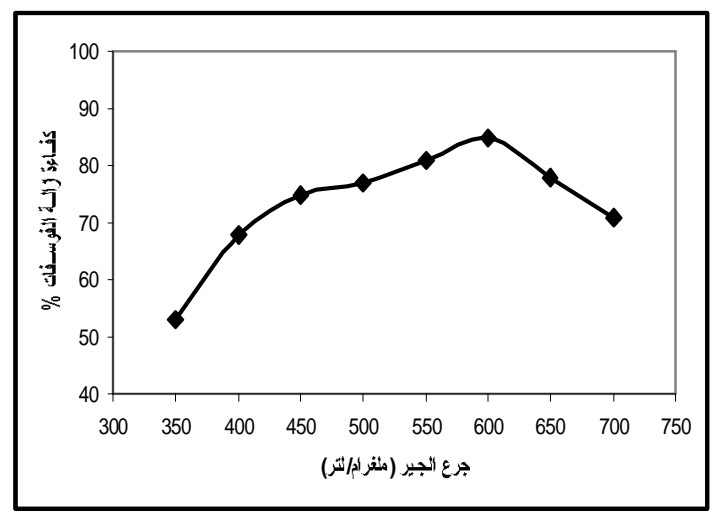

الثكل رقم (3) يوضح نأثيْر جرع الجير على كفاءة ازائة القوسفات (30) من مياه فضلات مجمح المستشفيات

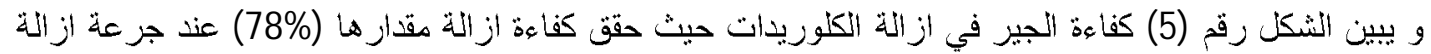

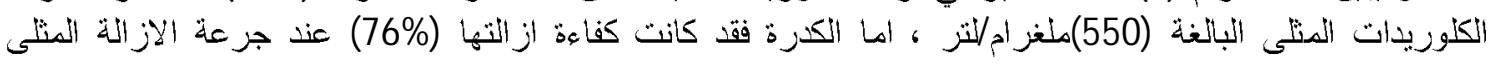

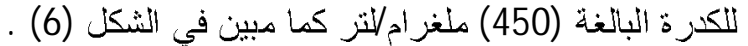

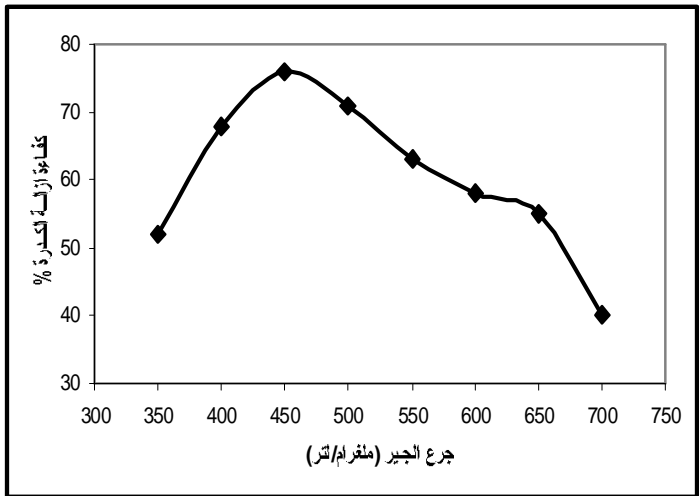

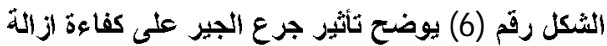

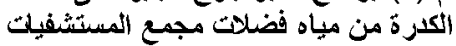

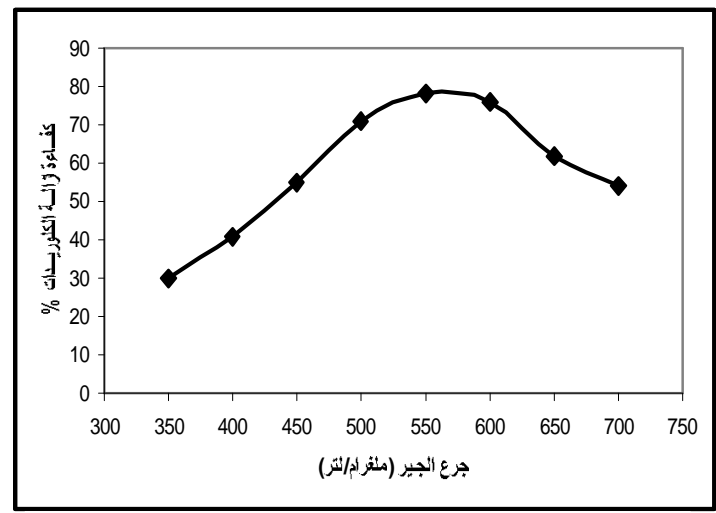

الثكل رقم (5) يوضح تأثير جرع الجير على كفاءةً ازائة

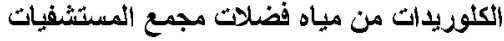

و قد ازيل (37\%) من الاملاح الموجودة في الماء الممثلة بقياس التوصيل الكهربائي (EC) عند الجرعة (400)

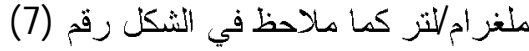




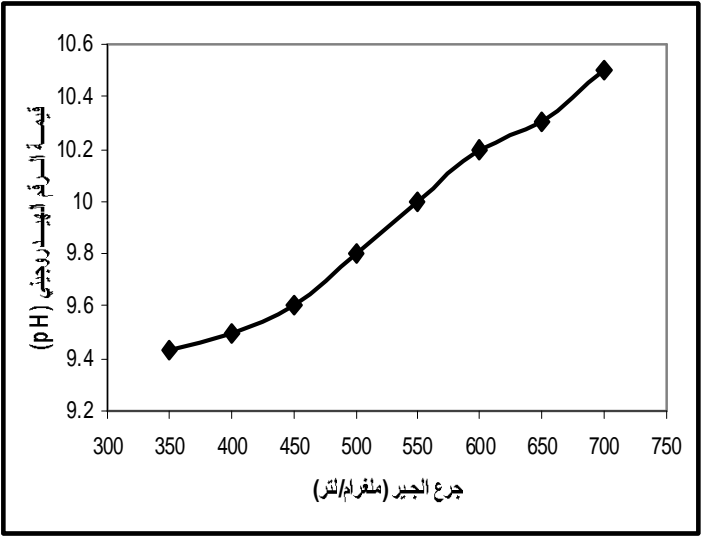

الثكل رقم (8) يوضح تأثبر جرع الجيز على فيم الرقم

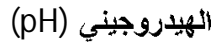

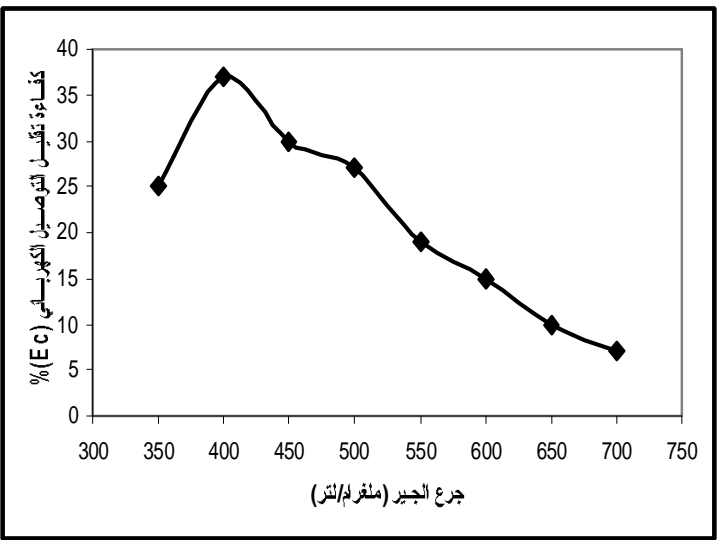

الثنكل رقم (7) يوضح تأثير جرع الجيز على كفاءة تقلثيل

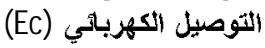

امسا الشكل رقم (8. (7) فيلاحظ فيه التغيز في قيمة الزقم الهيدروجيني (pH) حيث كانت القيمة الأولية للماء الخام مقدارها

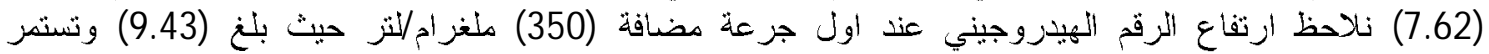

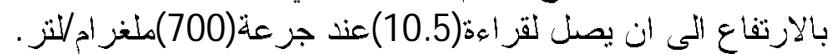

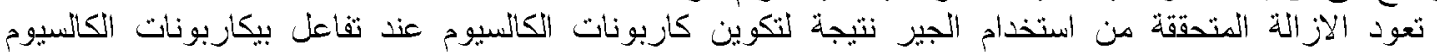

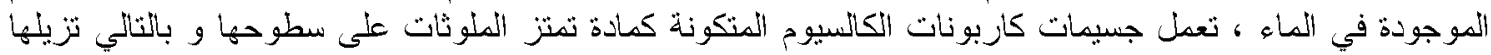

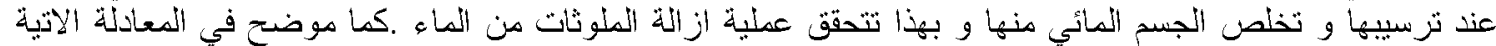

$$
\mathrm{Ca}(\mathrm{OH})_{2}+\mathrm{Ca}\left(\mathrm{HCO}_{3}\right)_{2} \rightarrow 2 \mathrm{CaCO}_{3} \downarrow+2 \mathrm{H}_{2} \mathrm{O}
$$

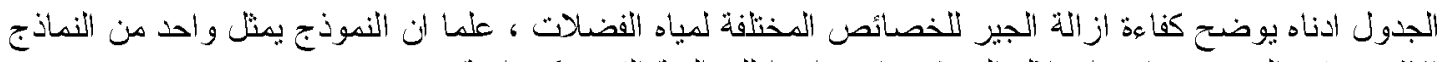

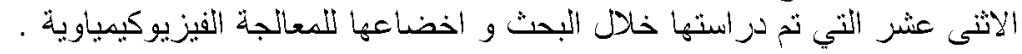

\begin{tabular}{|c|c|c|c|c|c|c|c|c|c|}
\hline هلغز إم/ & هلغز أم/ & ملغر إم/ & هلغز ام/ لتز & لتغز إم/ & ملغز أجما & ملغز أم/ 400 & 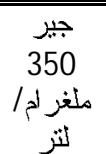 & نموذائص & الخاصية \\
\hline 204.6 & 187 & 178 & 167 & 136.4 & 127.6 & 92.4 & 112 & 220 & ملغر اد//تزر \\
\hline 470 & 421 & 378 & 345.6 & 270 & 248 & 178 & 281 & 540 & $\begin{array}{c}\text { T.S } \\
\text { ملغر اد/لثر }\end{array}$ \\
\hline 2 & 1.65 & 1.1 & 1.4 & 1.7 & 1.87 & 2.4 & 3.5 & 7.5 & ملغر ام/اتثر \\
\hline 0.6 & 0.57 & 0.54 & 0.5 & 0.48 & 0.378 & 0.35 & 0.4 & 0.7 & ملغز اجد/تثر \\
\hline 19 & 16 & 10 & 9 & 12 & 19 & 24.7 & 29.4 & 42 & ملغز اج/ينتز \\
\hline 33 & 24.7 & 23 & 20 & 16 & 13 & 17.6 & 26 & 55 & $\begin{array}{l}\text { كدرة } \\
\text { NTU }\end{array}$ \\
\hline 679 & 657 & 620 & 591 & 533 & 511 & 460 & 547 & 730 & 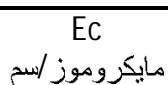 \\
\hline 10.5 & 10.3 & 10.2 & 10 & 9.8 & 9.6 & 9.5 & 9.43 & 7.62 & $\mathrm{pH}$ \\
\hline
\end{tabular}




$$
\text { تأثثير جزع الثب على كفاءة الاز الثة : - }
$$

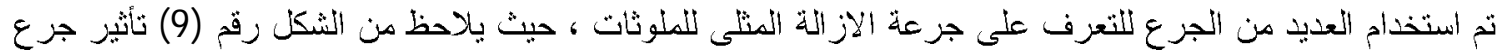

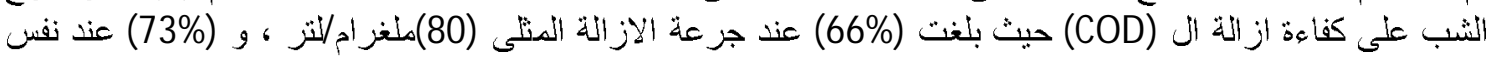

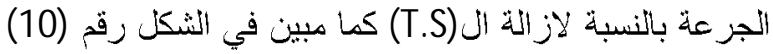

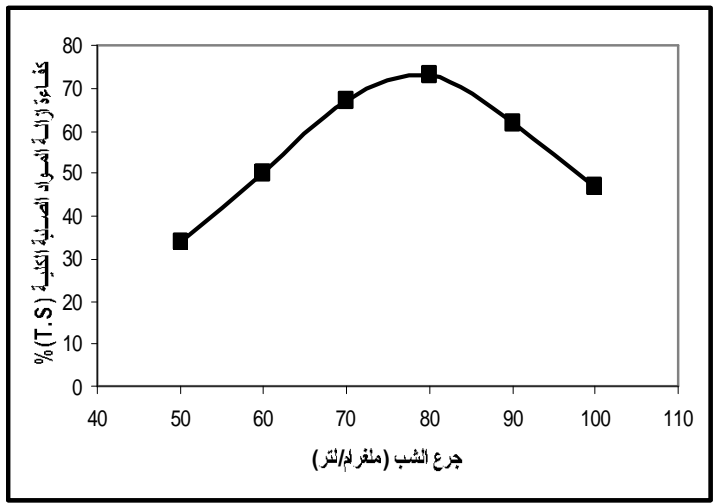

شكل رثم(10) يوضح ثأثير جرع الثب على كفاية ازالة ال(T.S) من مياه فضلات مجمي المستشفيك

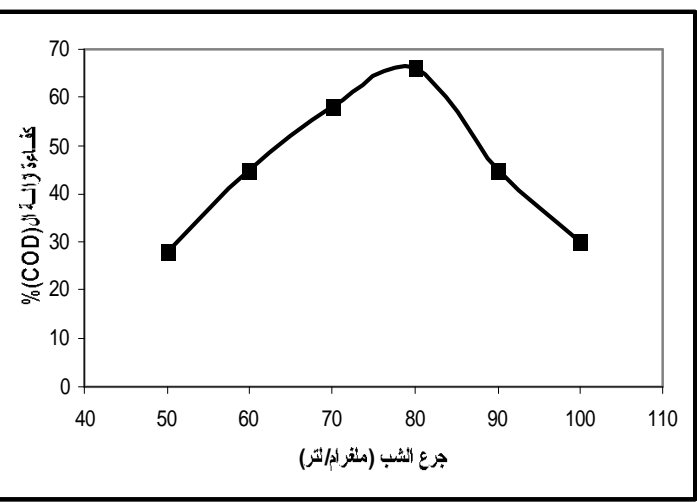

شكل رقمام(9) بوضح نأثير جرع الثب على كفاءة ازالةقال(COD) من مباد فضلات مجمع المستشفيات

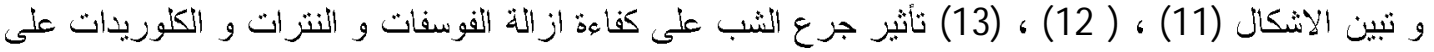

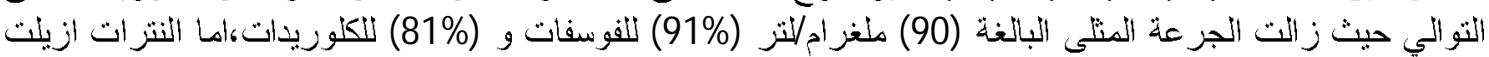

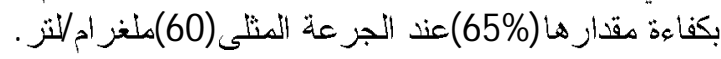

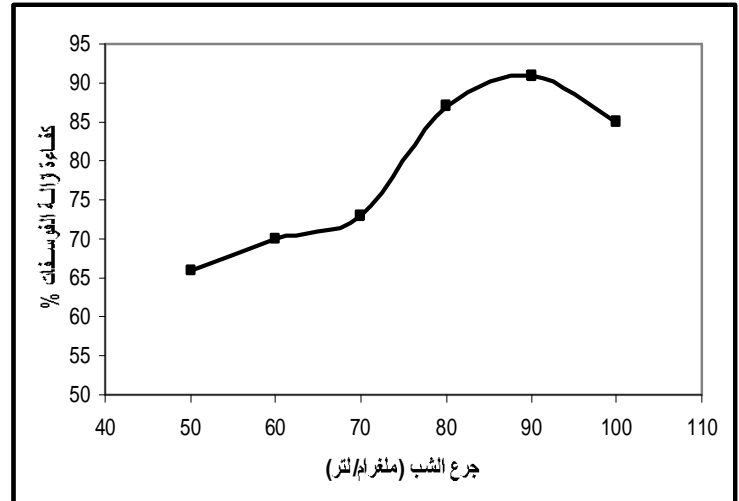

الثكل رقم (12) يوضح تأثيّر جرع الثبب على كفاءة ازالثة النترات (NO3) من مياه فضلات مجمع المسنتشفيات

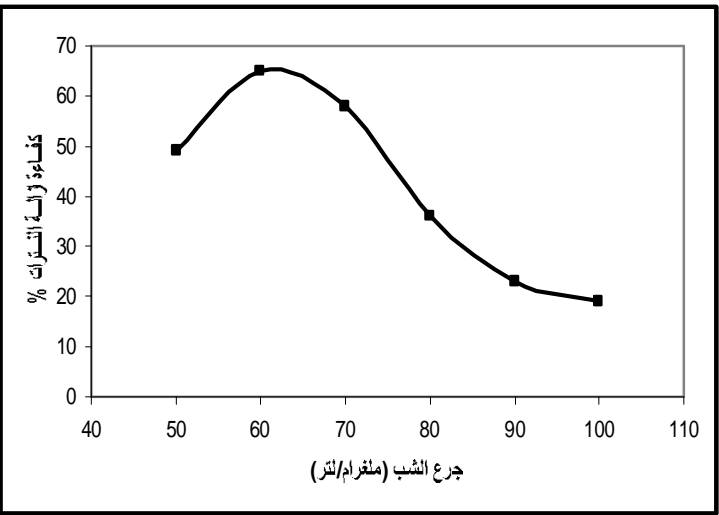

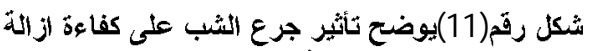

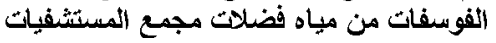

و ييين الثكن رثم (14) نتائج نأثير جزع الثبب على ازالة الكزة حيث وصلت اعلى ازالة عند الجزعة المثلى

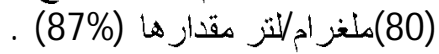

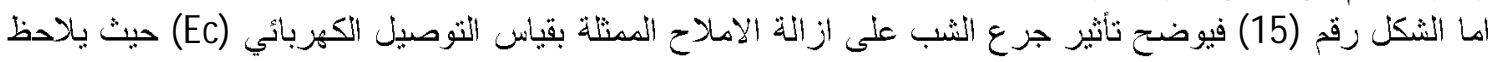

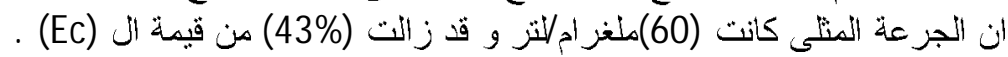

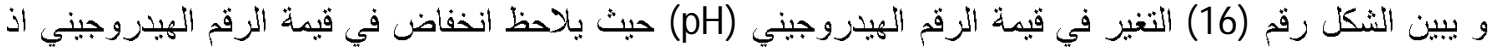

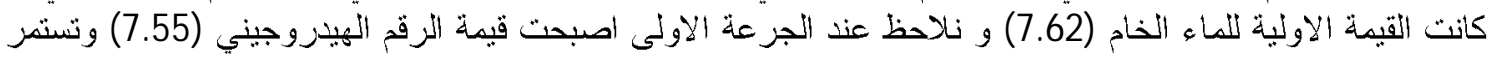

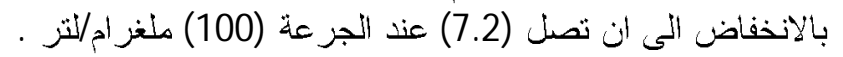




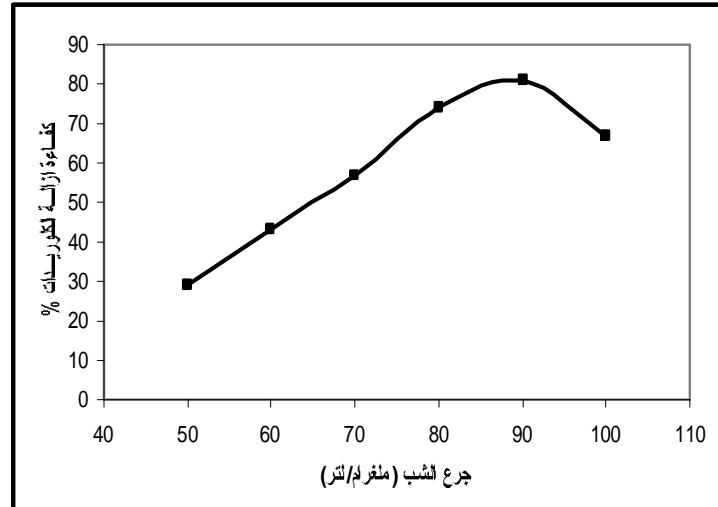

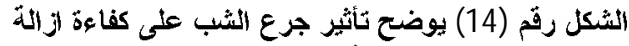
الكلدة من مياه فضلات مجمع المسنتشفيت

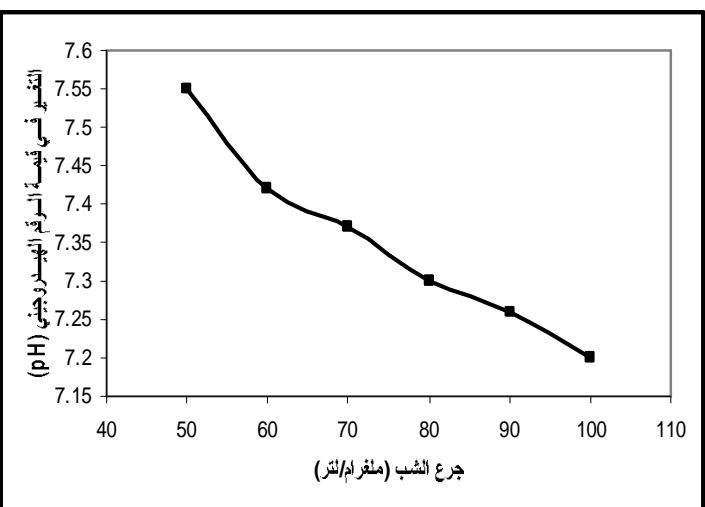

الثكل رقم (16) يوضح نأثير جرع الثب على قيتم الرقم الهيدروجيني (pH) لمياه فضلات مجمع المستشفيك فئر

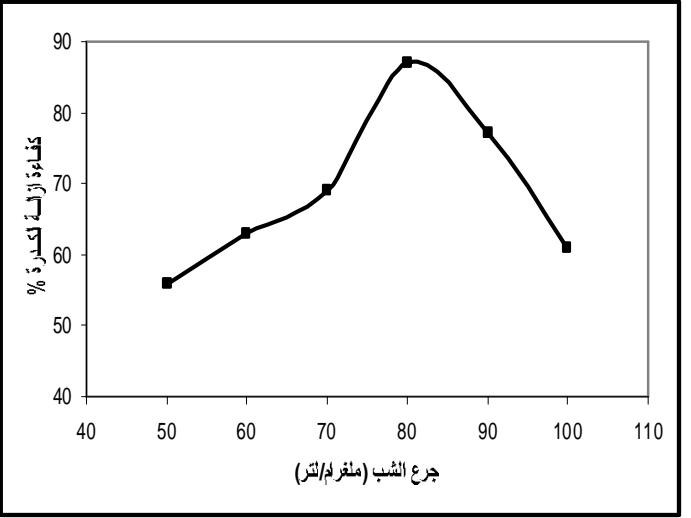

الثكل رقم (13) يوضح تأثير جرع الثُب على كفاءدة ازالة الكلوريدات من مياه فضلات مجيع المسنثفيات

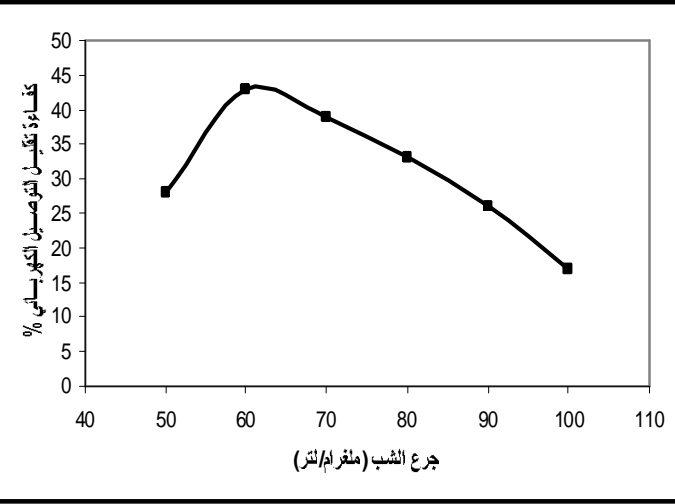

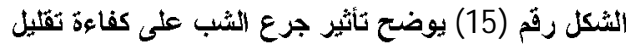

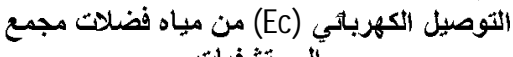

تعود كفاءة الشب العالية في ازالة الملوثات الى نكون ملبدات هيدروكسيد الالمنيوم

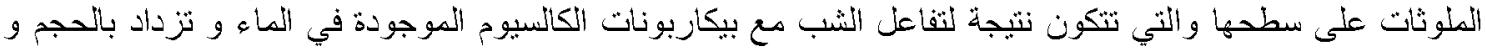

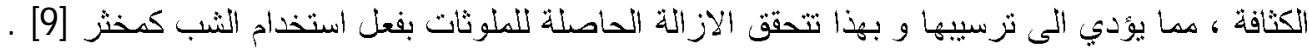

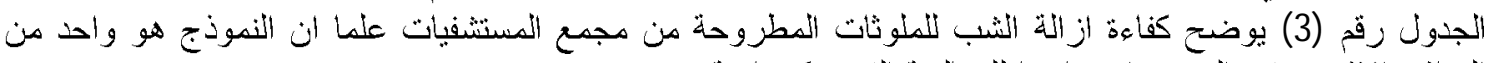

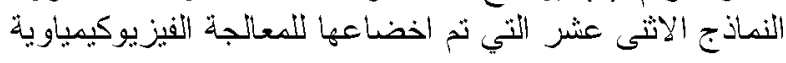

جنول رقم (3) يوضح كفاءة ازالة الثب للخصائص المختلفة لمباه فضلات مجمع المستشفيات

\begin{tabular}{|c|c|c|c|c|c|c|c|}
\hline ملغر الخلتزر & ملغر ائلتز & ملغر امخلتر & ملغر آحلثز & ملغر احخلثر & ملغر اجملثنر & نموذج & الخاصية \\
\hline 154 & 121 & 74.8 & 92.4 & 121 & 158.4 & 220 & Cلغز اح/لثز COD \\
\hline 286 & 205.2 & 145.8 & 178.2 & 270 & 356.4 & 540 & T.S ملغر اح/تنز T.S \\
\hline 1.125 & 0.675 & 0.975 & 2.02 & 2.25 & 2.55 & 7.5 & فوسفات ملغر ام/لتزر \\
\hline 0.567 & 0.539 & 0.448 & 0.294 & 0.245 & 0.357 & 0.7 & نتزات ملغر ام/تثز \\
\hline 13.8 & 8 & 11 & 18 & 23.94 & 29.8 & 42 & كلوربيات ملغرام/لتز \\
\hline 21.45 & 12.65 & 7 & 17 & 20 & 24 & 55 & Sكرة NTU \\
\hline 606 & 540 & 489 & 445 & 416 & 709 & 730 & Ec مايكروموز/سم \\
\hline 7.2 & 7.26 & 7.3 & 7.37 & 7.42 & 7.55 & 7.62 & $\mathrm{pH}$ \\
\hline
\end{tabular}




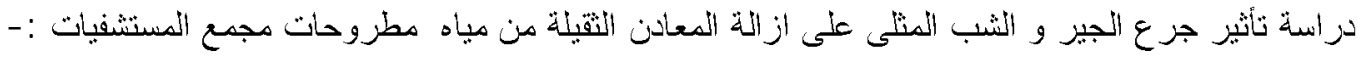

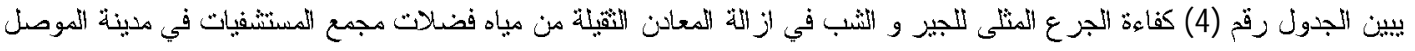

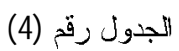

\begin{tabular}{|c|c|c|c|c|c|}
\hline كفاءة الالز الثة & 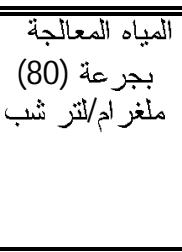 & كفائة الازيزة & لبز الكياه المعالجة (400) & اللمباه الخام & الكعدن \\
\hline$\% 97$ & 0.008 & $\% 89.28$ & 0.03 & 0.28 & الزملفراص/تنزر) \\
\hline \%97.8 & 0.0033 & $\% 95$ & 0.008 & 0.157 & 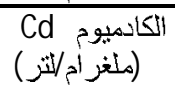 \\
\hline$\% 97.35$ & 0.083 & $\% 94$ & 0.19 & 3.1413 & الخلز صنين التزي) \\
\hline$\% 96.54$ & 0.044 & $\% 91.75$ & 0.105 & 1.274 & 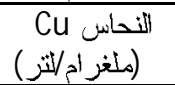 \\
\hline
\end{tabular}

كفاءة محطة المعالجة الحالية في از الة الملوثات المختلفة : -

يوضح الجدون رقم (5) قيم نر اكيز الملوثات المدزوسة في المباد الخام بالاضافة المى المباه الخارجة من المحطة التي

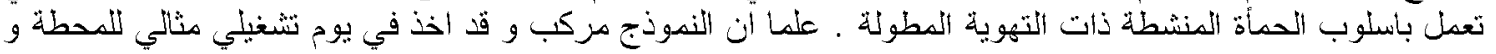

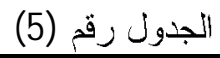

\begin{tabular}{|c|c|c|c|}
\hline كفاوة الآز اللة لدحطة & الكياه الخارجة من محطة & المياه الخام & الخصائص \\
\hline 47.7 & 184 & 352 & 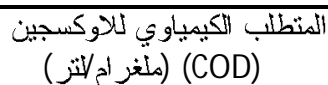 \\
\hline 25.8 & 712 & 960 & الموائ الصلبة الكلية (T.S) \\
\hline 6.15 & 6.1 & 6.5 & فو سفات (PO4) (ملغز اد/لتزر) \\
\hline 9.37 & 2.9 & 3.2 & تنز ات (NO3) (ملغر اح/ثنر) \\
\hline 29 & 33.4 & 47 & كلوريدات (ملغز ام/لتزر) \\
\hline 36.6 & 39.3 & 62 & كدرة: (NTU) \\
\hline 30.66 & 789 & 1138 & التوصيل الكهزبائي (EC) \\
\hline$\overline{---}$ & 7.9 & 7.84 & الزقم المهيدروجيني (pH) \\
\hline 39 & 0.17 & 0.28 & الز صاص (pb) (ملغز اد/لتزر) \\
\hline 38 & 0.097 & 0.157 & الكادميو (Cd) (ملغز اج/ آتر ) \\
\hline 40 & 1.887 & 3.1413 & الخار صين (Zn) (ملغر ام/لتزر) \\
\hline 46.4 & 0.683 & 1.274 & النحاس (Cu) (ملغز اد//تزر ) \\
\hline
\end{tabular}

مقازنة كفاءة الازالذة المتحققة من المعالجة الفيزيوكيمباوية باستخدام جرع الجير و الثبب المثلى مع كفاءة الازاتلة المتحققة في محطة المعالجة البانيولو جية القائمة حلأيا: - 
يوضح الجنول رقم (6) مقازنة بين كفاهة الاز الة المندققة من جرع المخثرات المثلى مع كفاءة محطة المعالجة الحالية

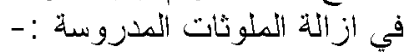

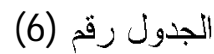

\begin{tabular}{|c|c|c|c|c|}
\hline كفائة محطة المعالجة & 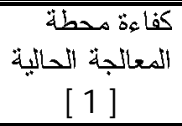 & 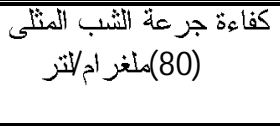 & كفاءة جرعة الجير المثلى & الخاصية \\
\hline$\% 47.7$ & $\%(50-89)$ & $\% 66$ & $\% 58$ & 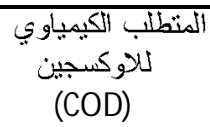 \\
\hline$\% 25.8$ & -- & $\% 73$ & $\% 67$ & $\begin{array}{c}\text { المو أد الصلئة الكلية } \\
\text { (T.S) }\end{array}$ \\
\hline$\% 6.15$ & $\% 25$ & $\% 87$ & $\% 68$ & الفوسفات (PO4) \\
\hline$\% 9.37$ & --- & $\% 36$ & $\% 50$ & النترات (NO3) \\
\hline$\% 29$ & --- & \%73.8 & $\% 41$ & الكلوريدات \\
\hline$\% 36.6$ & --- & $\% 87.27$ & $\% 68$ & الكبرة \\
\hline$\% 30.6$ & --- & $\% 33$ & $\% 37$ & $\begin{array}{l}\text { التوصيل الكزربائي } \\
\text { (EC) }\end{array}$ \\
\hline$\% 39$ & -- & $\% 97$ & $\% 89.28$ & الزصاص (pb) \\
\hline$\% 38$ & --- & $\% 97.8$ & $\% 95$ & الكادميو د (Cd) \\
\hline$\% 40$ & --- & $\% 97.35$ & $\% 94$ & الخارصبن (Zn) \\
\hline$\% 46.4$ & --- & \%96.54 & \%91.75 & النحساس (Cu) \\
\hline
\end{tabular}

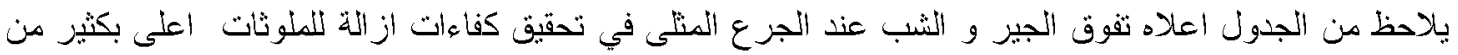

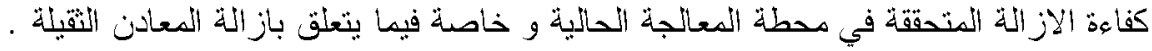

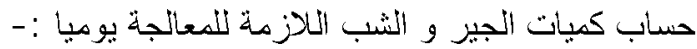

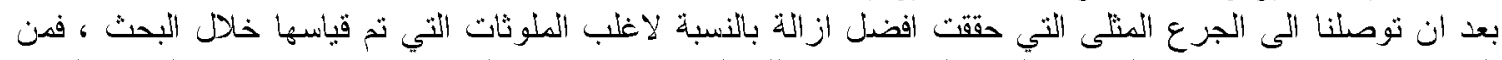

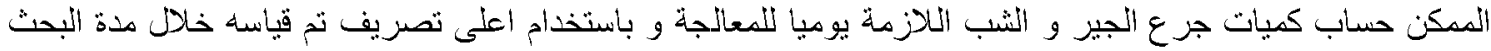

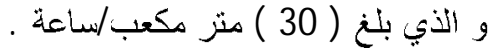

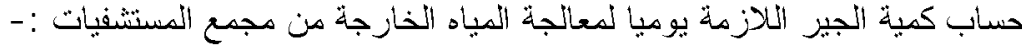

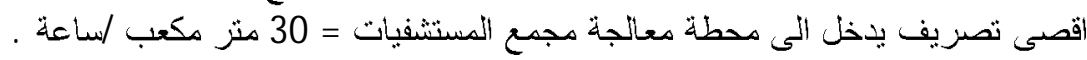

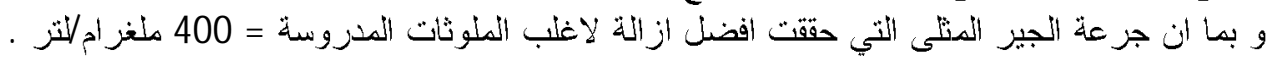

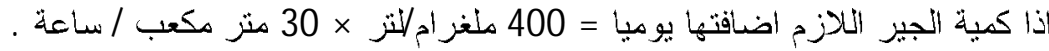
$(1000 \times 1000) \backslash(30 \times 1000 \times 400)=$

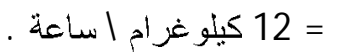

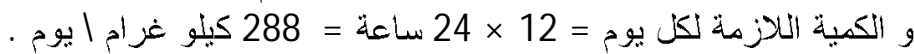
اما بالنسبة لحساب كمية الثب التلازية اضافتها يو مبا

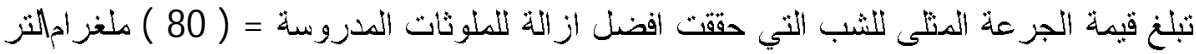

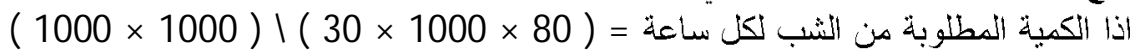
. 2.4 كيلو غزام \ساعة × 2.40 و انكمبة المطلوبة من التُب لكل يوم= 2.4 × 24 ساعة . $57.6=$

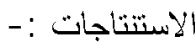
1 - حقق الثب كفاءة اعلى مما حققه الجيز في از الة الملو ثات من مياد فضلات مجمع المستشفيات في

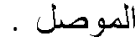

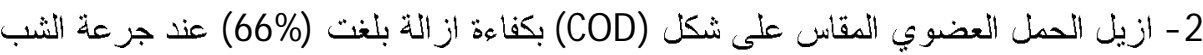

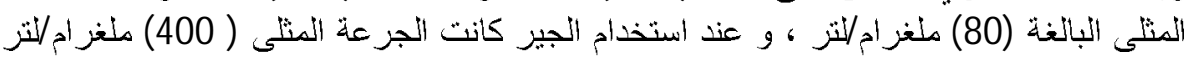




$$
\text { و كفاءة الازالة (58\%) . }
$$

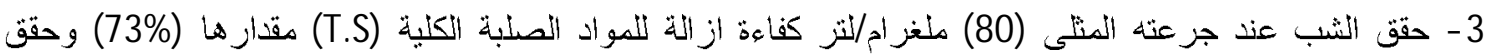

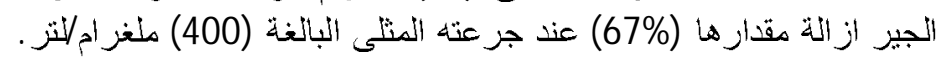

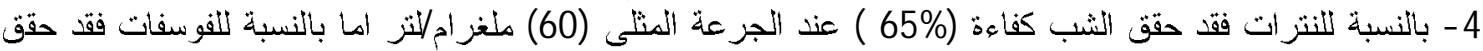

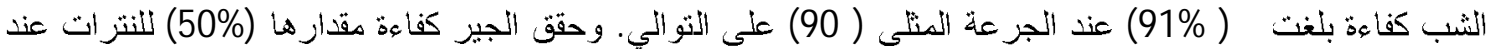

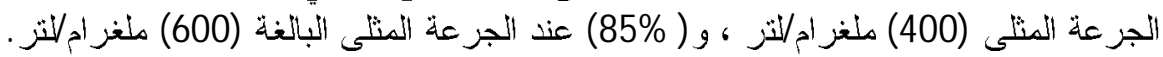

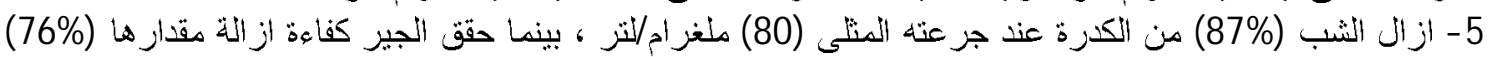

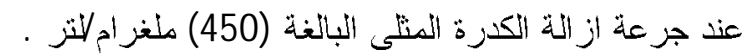

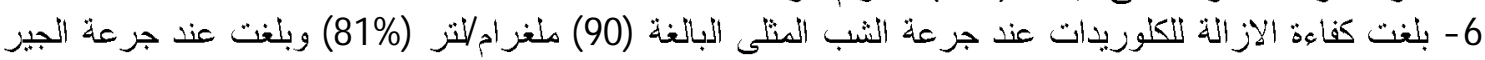

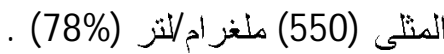

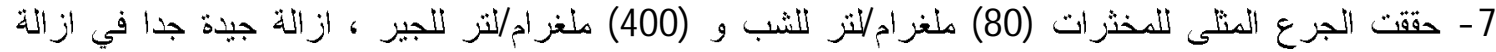

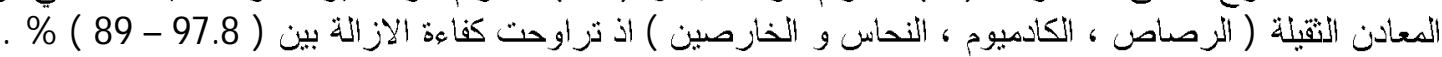

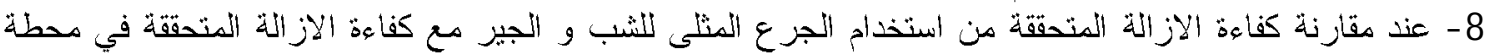

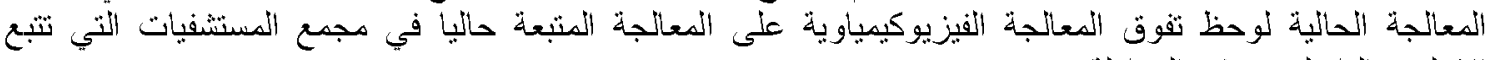

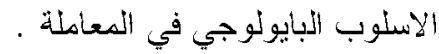

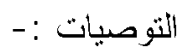

1 - عراسة استخدام مساعدات التخثير مع المخثرات المستخدمة (الجير و الثب) و تأثيرها في تحسين كثاءة الإزالة و

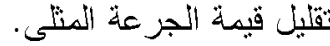
2 - دراسة استخام المعالجة الفيزيوكيمياوية كمعالجة مسبقة على المباه الخازجة من المختبزات فقط و تاثيرها على تحسين كفاءة المعالجة البايولوجية .

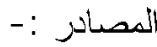
اللكيمي ، سفيان محد سعيد ، "تقييم كفاءة المعالجة البايولوجية لبعض المستشفيات في مدينة الموصل" ، اطروحة ماجستيز ، كلية الهندسة ، جامعة الموصل (2002).

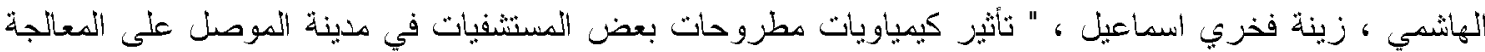
البايولو جية لمياه الفضلات " ، اطروحة ماجستيز ، كلية الهندسة ، جامعة الموصل (2005).

عباوب ، سعاد عبد و حسن ، محد سليمان ، "الهندسة العملية للبيئة - فحوصات الماء" ، دار الحكمة للطباعة و النشر ، الموصل (1990).

مصطفى ، معاذ حامد و حنا ، غيداء خضر ، "دراسة تحليلية لمخلفات المستشفى العام والجمهوري و الولاده":مجلة

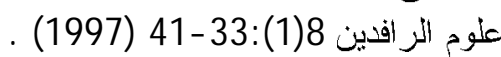

Adams,C. ; ASCE,M. ; Wang, Y. ; Loftin,K. and Meyer, M. ; "Removal of Antibiotics from Surface and Distilled Water in Conventional Water Treatment Processes " , J. Envir. Eng. , Vol. 128 , 3 , pp. 253-260 (March 2002) .

Al-Layla, M.A. ; Ahmad, Sh. And Middlebrooks, E.J., "Handbook of wastewater collection and treatment ", Garland STPM Press, New York and London (1980).

Al-Rawi, S.M.; Hana, G.Kh. and Ali, A.R., "Performance of Two Hospital Wastewater Treatment Plants in Removing Various Pollutants ", Al-Muhandis ，123: 17-24 (1997) 
Gautam, AJAY K. ; Sunsil , Kumar ; P.C. , Sabumon ; "Preliminary Study of PhysioChemical Treatment Options for Hospital Wastewater " , J. Environment Management, Vol. 83 , No.3 , pp.(298-306), (2007).

Kiley, G., "Environmental Engineering ", McGraw- Hill Published Company, England (1997).

Kugelman, I.J. and Carty, P.L., " Cation toxicity and simulation in anaerobic waste treatment ", $19^{\text {th }}$, Industrial Waste Conference, USA , 667 ( 1974) .

Metcalf and Eddy, "Wastewater Engineering", $\quad 2^{\text {nd }}$ ed., Mc Graw-Hill, Inc. New York, USA. (1979).

Randtke, J.S., " Organic contaminant Removal by Coagulation and Related Process Compination", J.American Water Works Association, 80, 5, 40(1988).

Standard Method for the Examination of Water and Wastewater, $16^{\text {th }}$ ed., APHA, AWWA, WPCF, New York (1985).

World Health Organization, "Mangment of Wastes from Health Care Activities, Geneva (1998).

$$
\text { تم اجر اء البحث في كلية الهنذسة - جامعة الموصل }
$$

